\title{
How Contracts And Culture Mediate Joint Transactions Of Innovation Partnerships
}

\author{
Jochen Schweitzer \\ University of Technology Sydney Business School \\ City Campus Haymarket \\ PO Box 123 Broadway \\ NSW 2007 Australia \\ Tel.: +61295143641 \\ Jochen.Schweitzer@uts.edu.au
}

Research for this paper was aided by support from the Centre for Management and Organization Studies at the University of Technology, Sydney as well as the Australian Research Council. We have also greatly benefited from the help and insightful comments of members of the Association of Strategic Alliance Professionals and the interviewed executives. All errors are our own. 
Although the literature suggests that matters of contracting and governance in strategic innovation partnerships are interrelated and that governance of partnerships generally occurs with contractual heterogeneity, our understanding about the specific relationships between contracting and the partnership culture that facilitates joint transactions is rather vague. In this study we clarify how the complexity of contractual agreements between partners in conjunction with the alignment of their innovation objectives and the ambiguity inherent in their mutual contributions to the partnership can be used to predict the culture of the partnership. We find that innovation partnerships result to be one of four types: bureaucratic, market, clan, or adhocracy. Our result emphasizes the central role of contractual complexity as a suitable and relevant concept to capture the nature of interorganizational innovation partnerships.

Keywords: Innovation partnerships, Contracting, Organizational culture

\section{Introduction}

Innovation has become the key strategy for many organizations to survive and grow in a very competitive and dynamic global environment. Strategic partnerships are an important means for organizations to achieve innovation objectives. Given the diversity and long history of innovation research, the term is notoriously ambiguous and often lacks a specific definition or measure (Adams, Bessant, \& Phelps, 2006) yet innovation is viewed by commercial, non-commercial and government organizations alike as an important approach to improving organizational efficacy and profitability. In this paper, we understand innovation in broad terms, following Schumpeter (1934), who includes five types of activity; new production methods, new sources of supply, the creation of new products, the capitalization of new markets, and organizing business in new ways, The latter in particular includes new approaches that are applied to create value for the organization and its partners.

Some of the key enablers of effective innovation have been explored and include strategic vision, culture, governance, and sense of urgency of the organization. Firms should balance exploitative and explorative ways of innovation and align their infrastructure, resources and organizational strategy to create dynamic innovation capabilities. However, the concept of developing unique competences within the organization as an exclusive source of competitive advantage is often inadequate in contemporary, disruptive, complex and global markets. Closed innovation based on self-reliance of 
R\&D is too slow and also costly to stay ahead of the competition. Thus, during the past three decades innovation has gone through evolutionary steps to collaborative innovation and more recently to open-innovation and co-innovation (Lee, Olson, \& Trimi, 2010).

In this paper we focus on collaborative innovation, which includes many new forms of partnerships, strategic alliances, joint ventures, and technology/patent relationships that have helped global leaders in their respective industries to combine their own core competencies with that of other world-class firms. Examples include such firms as Nike, Apple, Cisco, HP, Dell, Rockwell Collins, KimberlyClark, Procter \& Gamble and many others that have created value and innovation by combining resources and - for example - forming partnership for joint research and development that have delivered sustained competitive advantage (Tapscott \& Williams, 2008).

These strategic partnerships are often defined so broadly that it is nearly impossible to differentiate them from other types of interfirm relationships like e.g. supplier relationships. As "hybrid" organizational forms they are a way to manage exchanges or relationships that are more complex than a standard market exchange since they involve purposive linkages (Kale, Singh, \& Perlmutter, 2000), exchange, sharing or co-development (Gulati, 1995b), yet do not merit full integration (Gulati, 1998; Williamson, 1991; Zenger \& Hesterly, 1997). Hence, we understand innovation partnerships as a unique form of organization, which in its simplest form can be defined as a group of stakeholders intentionally organized to accomplish an overall, common innovation goal or set of innovation goals, which are explicit or implicit, carefully considered and established through a strategic planning process.

Generally, partnerships have been shown to be effective mechanisms for transferring knowledge (Doz, 1996), spreading risk (Hennart, 1988), and learning (Inkpen \& Crossan, 1995). Other studies have examined a host of further factors that relate to how partnerships are structured and their role in achieving strategic advantage. This growing body of research has also dealt with several aspects of innovation partnerships and found that the ability to successfully set up and manage them is affected by the contracting and governance arrangements that are put in place. Similarly, research suggests a positive and significant role of organizational culture or climate on innovation (Ahmed, 1998; Isaksen, Lauer, Ekvall, \& Britz, 2001; Lee, Tan, \& Chiu, 2008) and that innovation within alliances can be achieved by creating a learning culture (Linnarsson \& Werr, 2004). The specific aspects of alliance contracting, governance and culture are inter-related, but no yet well understood. Therefor, 
in this paper our focus is on examining contractual complexity and alliance culture including their antecedent factors as the key aspects for effectively mediating transactions of innovation partnerships.

We present and empirically assess a conceptual framework to contribute to the academic literature. By embedding our framework in organizational control theory (Ouchi, 1980) and theoretical developments on organizational culture (Cameron \& Quinn, 2011) and alliance contracts and contractual complexity (Ariño \& Reuer, 2006a; Reuer \& Ariño, 2007) we provide a more comprehensive explanation of the interplay of contractual complexity and organizational culture within innovation partnerships. Showing that contractual complexity, goal incongruence and performance ambiguity profile the culture of innovation partnerships extends present conjectures and allows us to better explain how aspects of the inter-organizational relationships relate to the success of innovation partnerships.

\section{Theoretical background}

Governance of innovation partnerships is about establishing alleged mechanisms that are used to influence and control partners, managers, and staff so that their decisions and actions serve the agreed and shared objectives. The alliance literature distinguishes relational and formal governance mechanisms (Hoetker \& Mellewigt, 2009) and also defines alliance governance structure traditionally by distinguishing non-equity and equity alliances. Formal governance mechanisms are policies, instruments, processes, and practices, which in innovation partnerships can involve, for example, a performance based compensation scheme for managers, the use of a board of directors as a means for decision making, the appointment of local innovation partnership managers, or the mutual agreement on formal provisions in a partnership contract. Relational governance in partnerships relates to social mechanisms that promote, for example, open communication and the sharing of information, trust, cooperation and other informal encouragement of a specific work ethic or work culture. The partners' choices and combination of governance mechanisms results in a distinct governance form (or structure), which represents the organizational context in which the partnership takes place (Ariño \& Reuer, 2006a).

Both, formal and relational alliance governance have been studied widely and are influenced by aspects like co-ordination costs and appropriation concerns (e.g. Gulati \& Singh, 1998; Oxley, 
1997); risks; partnership task-scope and transaction-level characteristics (e.g. Oxley, 1999; Oxley \& Sampson, 2004); technological intensity (Osborn \& Baughn, 1990); strategic motivation (Nielsen, 2003); division of labor (Reuer, Zollo, \& Singh, 2002); task complexity and inter-partner diversity (White \& Lui, 2005); trust among partners (e.g. Gulati, 1995a; Krishnan, Martin, \& Noorderhaven, 2006; Lui \& Ngo, 2004; Nooteboom, Berger, \& Noorderhaven, 1997; Zaheer, McEvily, \& Perrone, 1998); and inter-organizational structures (e.g. Gerwin \& Ferris, 2004; Ring \& Van de Ven, 1994; 1992). The management and control of these factors is reflected in the use of contractual provisions between partners (e.g. Reuer \& Ariño, 2003; Reuer, Ariño, \& Mellewigt, 2006; Sampson, 2004), that is, partners use contracts to define mutual rights and obligations by specifying resource allocations, practices of interaction and problem solving, as well as expected outputs (e.g. Argyres, Bercovitz, \& Mayer, 2007; Ariño \& Reuer, 2006a; Lerner \& Merges, 1998; Luo, 2002). These arrangements provide the basis for operating the partnership.

In this way, contractual arrangement and governance mechanism correspond not only with the structure of the partnership, but also its culture.

The organizational culture of the partnership, however, is also a function of the underlying values and beliefs of the people who are operating it and thereby define in a basic taken-for-granted fashion the partnership's view of itself and its environment (Schein, 2010). These beliefs and expectations serve as a normative order that influences how people perceive, think, feel and behave (O'Reilly, 1989). As such, culture may directly or indirectly influence partnership governance and related contractual complexity or vice-versa. While understanding the role of culture remains a difficult task due to its elusive nature (Duncan, 1989), it certainly plays an integral part both as a reflection of and influence on characteristics of innovation partnerships including - for example - the formality and centrality of decision-making, or the extent to which actions are based on mutual understanding and trust.

Hence, while governance and culture of innovation partnerships are naturally related, they are also associated with contractual specifications and related complexity. Here, we focus on the emergent organizational culture of the partnership and utilize organizational control theory to explain the occurrence of alternative types of partnership cultures.

The organizational control perspective (Ouchi, 1980) and later additions (Cameron \& Ettington, 1988; Mintzberg, 1993) suggest that different organizational cultures can be classified in terms of 
archetypes, namely market, clan, bureaucracy, adhocracy or any hybrid form of these. These types reflect the goal incongruence and performance ambiguity among partners (Cameron \& Quinn, 1999; Ouchi, 1980). Goal incongruence refers to the fact that the goals of partners may not be entirely consistent, describing a state of diverging preferences or a lack of overlapping goals. Performance ambiguity, on the other hand, arises when the measurement of the partners' contributions within the partnership is subject to uncertainty.

Accordingly, antecedent factors to culture including levels of goal incongruence and performance ambiguity result in any one of four archetype cultures being the most efficient to mediate joint transactions: market culture is efficient when performance ambiguity is low and goal incongruence is high, bureaucracy is efficient when both goal incongruence and performance ambiguity are high, clans are efficient when goal incongruence is low and performance ambiguity is high (Ouchi, 1980), and, finally, adhocracies are efficient when goal incongruence and performance ambiguity are low (Cameron \& Ettington, 1988; Mintzberg, 1993). The market culture type values productivity and efficiency; information is assumed complete and partners are aware of an explicit competitive price for each task or exchange. With a focus on achievement, this culture emphasizes centralized decision making and more formal coordination and control systems. The partners' commitment to the joint organization's objectives is obtained by self-interest and based on the price mechanism.

Bureaucracies involve close personal surveillance and direction of subordinates by superiors with the information that is necessary for task completion being contained in rules. The cost of administration in bureaucracies is typically high. This culture values stability and control and emphasizes formal coordination, centralized decision-making and vertical communications where team members' roles are defined and enforced through formal rules and regulations.

The clan culture adds a social dimension in assuming that in situations of great uncertainty and complexity, managerial control is established through the group's system of beliefs and perceptions rather than through its behavior or output. Accordingly, in clan culture it is assumes that individuals are acculturated into a system of controls and meanings. Structurally, there is less emphasis on formal coordination and control systems, and a greater emphasis on participation, decentralized decision-making, horizontal communications and teamwork.

Lastly, adhocracies represent a highly organic and unordered organizational culture. Members within an adhocracy generally perform complex work in small teams with substantial personal 
communication. Adhocracy is designed to be flexible and adaptable to rapidly changing environments; it emphasizes growth and adaptability. Similar to the clan culture, there is an emphasis on informal coordination, control systems and horizontal communications (Quinn, Hildebrandt, Rogers, \& Thompson, 1991; Zammuto \& Krakower, 1991).

The four cultural orientations are also confirmed by research that examined the relationship between organizational culture and effectiveness (Quinn \& Rohrbaugh, 1981) where it was shown that changes in effectiveness could be explained by an organization's attention inward (toward internal dynamics) versus outward (toward external environment) and its preference for governance to depict flexibility versus control (Goodman, Zammuto, \& Gifford, 2001).

Although organizational control theory does not explicitly consider aspects of contractual complexity, we suggest that it can assist in providing a suitable theoretical underpinning to examine contractual complexity as an additional and important influence on culture in inter-organizational situations.

We also consider the role and importance of contractual complexity of partnership agreements between innovation partners. The much observed heterogeneity of partnership agreements is based on variations in contractual complexity, which in turn reflects the often very different relational and situational characteristics of the partnership. Indeed, previous studies have suggested that complexity of agreements is the central concept of contracting (Reuer \& Ariño, 2003). Following this work we understand contractual complexity as a design feature of the partnering firms' agreements that reflects the number and stringency of the provisions that are being employed. Important aspects and antecedents of contractual complexity include asset specificity of the partnership, existence of prior ties among partnering organizations, time boundedness of the agreement, strategic importance of the partnership, and partner search costs (Reuer \& Ariño, 2003). ${ }^{1}$ Although this work captures important aspects of contractual complexity, there are possibly additional factors like types of relational or environmental uncertainty, or the frequency of transactions among partners, that affect the complexity of partnership agreements. Recognizing the early stage of research in understanding

\footnotetext{
${ }^{1}$ Asset specificity is the extent of the partners' transaction-specific investments for the partnership; prior ties captures the role of previous partnerships; time boundedness is about the duration to operate the initiative; strategic importance is about the significance that partners give to their collaborative venture; and, finally, partner search concerns the costs that are associated with finding, evaluating, and negotiating with potential partners.
} 
antecedents of contractual complexity we focus on the not yet systematically studied link between contractual complexity and partnership culture.

While the different archetypes featured by the organizational control perspective address and explain social, cultural, and relational aspects of the partnership culture, the theory does not explicitly take into account the complexity of contractual provisions between parties; complexity that is heterogeneous across different types of partnerships. Yet, the conceptualization of contractual complexity (Ariño \& Reuer, 2006a) and organizational culture (Ouchi, 1980) share theoretical foundation in transaction cost economics. Both perspectives assume environmental uncertainty, asset specificity, bounded rationality, and behavioral uncertainty to result in transaction costs that mediate the characteristics of the relationship between partnering organizations as well as their joint transactions. Hence, we consider the organizational control perspective as a suitable theoretical basis to address the role of contractual complexity in innovation partnerships because both goal incongruence and performance ambiguity share antecedents with contractual complexity.

Goal incongruence, for example, is linked to asset specificity through related levels of decisionmaking uncertainty and trust among alliance members; it relates to partner search costs through associated efforts of strategic goal alignment in the process of finding innovation partners; it is associated with prior ties through the degree of behavioral uncertainty and trust among partners; and it relates to the time boundedness of the partnership through the partners' ability to better predict environmental uncertainties when the duration of the partnership is predetermined.

Performance ambiguity too, is linked to prior ties through existing experience and trust among partners, and it relates to time boundedness through potentially opportunistic partner behavior in fixed term partnerships. In addition to the common set of antecedents, recent research has shown that variation in partnership governance can also be attributed to contractual complexity (e.g. Reuer \& Ariño, 2007), a concept distinctively different to both goal incongruence and performance ambiguity.

Hence, we need to further investigate relationships between contractual complexity and organizational culture, as well as the relationships of contractual complexity with performance ambiguity and goal incongruence. We suppose that the organizational control perspective provides not only a comprehensive explanation for organizational cultures of innovation partnerships but also 
a suitable theoretical foundation for our framework that addresses the influence of contractual complexity on the resulting organizational culture of innovation partnerships.

\section{Hypotheses}

\subsection{Effects of goal incongruence and performance ambiguity on contractual complexity}

When innovation partners negotiate contractual provisions, they consider the extent to which their objectives are corresponding as well as whether they are able to assess mutual contributions to the partnership or learn from each other (e.g. Doz, Olk, \& Ring, 2000; Hennart, 1988). These two central aspects of inter-organizational collaboration are captured by the partners' perception of goal incongruence and performance ambiguity. We suggest that there are also relations between goal incongruence, performance ambiguity and contractual complexity.

Goal incongruence affects contractual complexity because alliance partners are likely to first achieve consistency of, and have a mutual understanding of, objectives before entering negotiations of detailed or suitably stringent contracts in order to safeguard their interests. Put simply, when goal incongruence is low (i.e. full goal congruence), contractual complexity is low, whereas in the case of significant goal incongruence, potential partners would either decide to not enter the partnership or opt for complex contracts. Performance ambiguity, on the other hand, influences contractual complexity because contract negotiation is more complex when it is difficult to measure outcomes or evaluate transactions (Barzel, 1982) and when tasks have little predictability (Demsetz, 1988). Conversely, when outcomes of the alliance are easily measurable and tasks are predictable, the complexity of contractual agreements, associated transaction costs, and the likelihood of renegotiation are low (Eisenhardt, 1985). However, contracts may also be left deliberately incomplete because performance is unverifiable (Bernheim \& Whinston, 1998). Either way, when it is difficult to distinguish the partners' contribution to the partnership and when inputs, processes, and outcomes are uncertain (Alchian \& Demsetz, 1972), innovation partners require more and detailed contractual safeguards to balance the uncertainty about the partners' capabilities and performance.

Furthermore, factors like asset-specific investments, incentive alignment, and loyalty (Alchian \& Demsetz, 1972; Ouchi, 1979; Williamson, 1975) help reduce goal incongruence. Both goal incongruence and performance ambiguity can be reduced through increased efficiency of the 
exchange as a result of cultural control (Ouchi, 1980; Wilkins \& Ouchi, 1983). Cultural control refers to a common set of beliefs, meanings, and values among the individuals who operate the partnership develop effective habits, conventions, and routines for their daily practice (DiTomaso, 1987; Scott, 1998). Cultural control requires time to evolve and might not be immediately effective in safeguarding opportunistic behavior when the collaborating organizations have no relational history. However, in cases of previous ties, cultural control can result in lower goal incongruence and performance ambiguity, leading to less complex contracts.

Also, when partner search costs are high, firms may achieve very low goal incongruence (i.e. goal congruence) due to intensive partner evaluation and goal alignment processes, which could result in few or no obligation to establish complex contractual safeguards. However, in case of high partner search costs and significant goal incongruence, a partner would avoid entering the alliance or safeguard its interests through a complex contract. The latter case then also indicates a high strategic importance of the alliance, which can also lead to increased complexity of contractual agreements. Hence, a significant effort to find a partner and agree a contract with a partner for the most part helps achieve a good and deep understanding of the partners' objectives (goal incongruence) and clarity about the partners' contributions to the alliance (performance ambiguity).

Finally, while the influence of time boundedness on contractual complexity is subject to perceived environmental and behavioral uncertainties (Ariño \& Reuer, 2006a), we suppose that these environmental and behavioral uncertainties correspond with perceived levels of goal incongruence and performance ambiguity among partners. Hence, the effect of the firms' intention to collaborate for a fixed versus undefined duration on the resulting complexity of contracts is mediated by the degree of goal incongruence and performance ambiguity among them. In sum, goal incongruence and performance ambiguity affect contractual complexity. We encapsulate the above in the following hypotheses:

Hypothesis 1: Greater goal incongruence between innovation partners is associated with greater contractual complexity.

Hypothesis 2: Greater performance ambiguity between innovation partners is associated with greater contractual complexity. 


\subsection{Effects of contractual complexity on partnership culture}

We argue that the culture of innovation partnerships may differ depending on the complexity of contractual provisions. That is, the various enforcing and coordinating aspects of contractual provisions that guide joint transactions provide control beyond safeguarding partners against unforeseen events or partner opportunism (Ariño \& Reuer, 2006a) since they, together with goal incongruence and performance ambiguity, influence the culture of the partnership. In what follows we discuss high, low, and moderate levels of contractual complexity and derive different effects for each of them.

Contractual complexity refers to the stringency of the provisions to control various aspects of the partnership. This can include, for example, enforcement provisions like a detailed account of property rights and knowledge sharing, or informational aspects like measures of performance for each partner organization. Poppo and Zenger (2002) assert that complex contracts are more detailed regarding the specification of promises, obligations, and processes for the resolution of disagreements. Complex contracts include details like roles and responsibilities to be performed or specific procedures for monitoring, consequences of non-compliance, and description of expected outcomes or output.

A bureaucratic culture emerges when the parties to a partnership seek to eliminate the potential for opportunistic behavior by quantifying and monitoring joint activities and mutual performance. Hence, within bureaucracies, partners assume that the majority of contingencies can be dealt with by policies, standardized procedures, formal division of responsibility, and hierarchical structures (Mintzberg, 1993), which are typically established within the contractual agreement for the partnership.

Low levels of contractual complexity, on the other hand, mean that there are few and lenient provisions agreed upon. Partners may deliberately choose to only agree on a few provisions and not control aspects of the partnership because of high information costs or because contract terms may not be enforceable or are assumed to evolve as the partnership unfolds. Partners may then find it necessary to renegotiate their contracts at some stage, either because they encounter situations in which the contract is silent or where the contract specifies inefficient terms. Yet, while a contractual agreement between collaborating organizations may only encompass a few agreements for a fraction of the partnership's scope, it can still enforce and entirely safeguard partners' interests for the given 
situation. A complex contract, in contrast, including less enforcement but more informational provisions, might fail to protect partners' interests because of a lack in stringency of the set provisions. Overall, less contractual complexity gives partners more flexibility to experiment with different ways to control and shape the innovation partnership, while at the same time exposing it to more risk involved with uncertain situations.

Within adhocracies formal and complex contractual agreements are rare because intensive informal interaction, spontaneity, casualness, and interpersonal familiarity act as their coordinating and integrating mechanisms (Jarillo, 1988). Because of these characteristics, adhocracies rely more on relational contracts (e.g. Bryant \& Colledge, 2002; Goldberg, 1976; Heide, 1994; Macaulay, 1963) than on explicit and formal contracts. That is, innovation partners demonstrate flexibility and solidarity while solving problems as they desire continuity in the relationship, so that increased cooperation, dependency, mutual trust, and commitment make it unnecessary to cover all contingencies in complex agreements (Anderson \& Weitz, 1992; Jeffries \& Reed, 2000). Low contractual complexity can therefore support the development of adhocracy cultures for innovation partnerships; it helps foster minimal formalization of procedures, a highly organic structure, and mutual long-term relationships (Achrol, 1997; Daft, 1995). It also allows partners to make decisions without the presence of hierarchical structures and policies (Cameron \& Ettington, 1988; Mintzberg, 1979).

Hence, the interplay of contractual complexity, performance ambiguity, and goal incongruence is associated with different organizational cultures. While high levels of contractual complexity, performance ambiguity, and goal incongruence may lead to bureaucracies, low levels of contractual complexity, performance ambiguity, and goal incongruence may lead to adhocracy governance. We encapsulate the above by advancing the following two hypotheses:

Hypothesis 3: High contractual complexity, high goal incongruence, and high performance ambiguity in alliances is associated with bureaucracy partnership culture.

Hypothesis 4: Low contractual complexity, low goal incongruence, and low performance ambiguity in alliances is associated with adhocracy partnership culture.

Moderate contractual complexity represents the partners' intention to balance between too much and too little control through contractual provisions. We associate the clan and market cultures with 
moderate levels of contractual complexity and suppose that moderate contractual complexity in combination with high performance ambiguity and low goal incongruence results in clan culture, while moderate contractual complexity in combination with low performance ambiguity and high goal incongruence results in market culture.

This is supported by the characteristics and the information requirements of clan and market cultures. In a partnership that has the attributes of a clan, trust and mutual understanding among the members usually reduces the need for monitoring, both in the pre-contractual and post-contractual phases. Consequently, the formal contracts that bind partners would likely display greater levels of completeness when opportunistic behavior is a possibility. On these grounds, Williamson and Ouchi distinguish between "hard" and "soft" contracting and argue that soft contracting represents the clantype culture. Hence, clan culture presumes that the identity of interests between the parties is much closer and formal contracts among parties are incomplete (Williamson, 1975). Further, clan culture is based on traditions where information is implicit; existing but mostly unstated (Ouchi, 1979), it is embedded in established systems of shared values and beliefs, common goals, and mutual understanding that, once adopted, are only moderately explicit and complex. While clan members may share general orientations but not necessarily specific knowledge (Williamson, 1975), they trust each other and trust the fact that know-how always stays within the clan, and that whatever action they take based on whatever knowledge they possess will ultimately be beneficial for all. Accordingly, there is less need to contractually formalize knowledge transfer, restrict knowledge sharing, and safeguard against knowledge spillover effects, since a common vision, shared objectives, and relational bonds among members of the clan predict those risks sufficiently.

The market culture, on the other hand, represents an open structure in which highly autonomous partners establish contractual relationships that are characterized by discrete, often short-term, agreements that aim to facilitate an economically efficient exchange. Partner performance is unambiguous because the conditions and agreements of the collaboration are specific, complete, and monetized. Hence, information requirements within market cultures are explicit, fully accessible, and easy to understand (Ouchi, 1979) so that a market culture is based on simple mechanisms following simple contracts. Moreover, within market culture, exchange objects tend to be nonspecific, that is, the resources, products, services or knowledge that a partner contributes can also be found with other partners (Macneil, 1978; Williamson, 1985). Therefore, highly complex contractual agreements are not necessary since the competitive marketplace and standard contract regulations 
and corresponding laws provide efficient safeguards to the parties for mediating their transactions (Ring \& Van de Ven, 1992). Besides, in a market culture, partners are equal and free, so that social relations among them are limited since developing them could incur costs or be irrelevant (Williamson, 1985). As a consequence, partners avoid the costs of agreeing on complex contracts that can influence and control their transactions. We encapsulate the above in the following final two hypotheses.

Hypothesis 5: Moderate contractual complexity, high goal incongruence, and low performance ambiguity in alliances are associated with market partnership culture.

Hypothesis 6: Moderate contractual complexity, low goal incongruence, and high performance ambiguity in alliances are associated with clan partnership culture.

\section{Method}

We conducted a study to assess the different effects of the previously described partnership culture and contract conditions and to examine whether the culture of innovation partnerships varies according to the interplay of contractual complexity, goal incongruence, and performance ambiguity. Managers of innovation partnerships were invited to provide their assessments of a single partnership experience.

\subsection{Sample}

To collect data we used the key informant method, which is an established way of gathering data (Philips, 1981), especially at the corporate level (e.g. Kale, Dyer, \& Singh, 2002; Simonin, 1997). Because the core variables of this study exist at the level of the partnership, we designed the research to target respondents who are highly knowledgeable about their firm's innovation partnerships. The partnership manager is both familiar with the contractual aspects, the governance arrangements and the characteristics of the partnership. We concluded that every manager with operational responsibility for the partnership is a suitable key informant (Kumar, Stern, \& Anderson, 1993) and we requested these managers to identify one specific, preferably well-established partnership that they had detailed knowledge about. Key informants were asked to provide details regarding their experience, including their role, tenure with the organization, the developmental stage and duration 
of the partnership, the number of partnering organizations, and how long the organizations had been working together.

We contacted managers who were members of the Association of Strategic Alliance Professionals (ASAP), which is the leading professional association of alliance management professionals that is dedicated to the discipline of business collaboration. In addition we contacted alliance manger via the professional business-networking platform Xing and through a global business panel. Overall, we received 327 responses representing a response rate of $23 \%$, which is similar to other studies on business collaboration (e.g., Heimeriks, Duysters, \& Vanhaverbeke, 2005; Kale et al., 2002; Reuer, Park, \& Zollo, 2002; Zollo, Reuer, \& Singh, 2002). The final data set consisted of 289 usable responses. All responses were from individuals who were or had been directly involved in innovation partnerships. The majority of participants $(66.4 \%)$ had been working for their organization for more than five years and $77 \%$ had been working for the focal partnership for more than two years. The overall response rate is adequate given the experience and seniority of respondents.

The three most frequently stated industry affiliations of participating managers were information technology (22\%), healthcare and life science (14\%), and consulting and professional services (11\%). The majority of participating organizations were based in North America (78\%), then Europe (16\%), Asia (5\%), and the rest of the world (2\%). Over $40 \%$ of the firms employed more than 1,000 employees, and 35\% generated sales revenue of over 100 million US\$. The innovation partnerships that the study participants focused on operated mainly at a global or multi-national level (46\%), fewer operated at a national level $(27 \%)$ or at a regional level $(28 \%)$. More than half $(65 \%)$ of the investigated partnerships were non-equity partnerships, and $21 \%$ were public-private partnerships.

In order to ensure that the data was not biased as a result of non-response we compared early and late respondents with respect to a number of key variables like the number of employees, sales revenues, and experiences with collaboration (Mohr \& Spekman, 1994; 2002). Chi-square tests showed that there was no difference between early and late respondents, which implied that there was no significant non-response bias in our data set (Armstrong \& Overton, 1977; Kanuk \& Berenson, 1975).

Gathering cross-sectional data also creates the potential for common method variance to be an explanation for the interrelationships observed amongst the study constructs. To minimize this 
possibility we designed the measurement constructs and the survey questionnaire thoroughly following the suggestions made by Podsakoff and co-authors (2003) and used Harman's singlefactor test to verify that common method bias is not present (Luo \& Tan, 2003). The presence of eleven factors with eigenvalues greater than one and the fact that the first factor only accounted for 15.33 per cent of the variance, suggests there is no serious problem with common method bias (Lane, Salk, \& Lyles, 2001).

\subsection{Instrument Development}

Existing scales were adopted and where it was not appropriate to directly use existing scales, modifications were made to suit the research context. Questionnaire items were pre-tested expansively. We verified the clarity of the items (DeVellis, 1991) in personal interviews with two practitioners and two experienced researchers, which helped gain a realistic understanding of the relevant practices of contracting, governance and culture of innovation partnerships and supported the suitability of the constructs for the measurement model. In a pilot study we sent 200 email invitations to managers who were registered members of the online professional businessnetworking platform Xing. From the pilot study we gained 38 usable responses, representing a response rate of $19 \%$, which we analyzed to evaluate the reliability of the constructs. In addition, the evaluation of the structural model using the partial least squares (PLS) estimation method indicated that the direction of predicted effects and the significance of related path coefficients were satisfactory. As a result of the analyses and additional feedback that we collected from pilot study participants, we were able to conclude with a workable questionnaire. Table 1 presents the measurement items for the key variables that were used in the final survey.

\subsection{Specification of the Measurement Model}

The explanatory variables in our study were goal incongruence, performance ambiguity, and contractual complexity. Goal incongruence is the degree to which preferences among innovation partners diverge or goals are inconsistent; it was measured using two reverse coded reflective items which were based on John and Reves' (1982) scale for goal compatibility. Participants rated for example, "The partnering organizations have consistent objectives" on a five-point scale from 1, "strongly disagree," to 5, "strongly agree." Performance ambiguity is the degree to which the partners' contribution and performance within the partnership is unclear and not easily measurable. 
We adapted two reflective items based on Stump and Hedes' (1996) scale for performance ambiguity which participants rated on a five-point scale. Statements included, for example "It is difficult to know whether our partner(s) do what they agreed upon."

Contractual complexity was assessed using a six item measurement construct including items for asset specificity, partner search costs, prior ties, time boundedness, and strategic importance (Reuer et al., 2006). Asset specificity is the degree to which partnering organizations commit resources like personnel, technology, and infrastructure to the partnership that are only utilizable within the context of the innovation partnership. We asked participants to rate a single item "We spend substantial effort and money on infrastructure that is dedicated exclusively to this partnership" on a five-point scale. Partner search costs are the costs of identifying suitable partners; it was measured on a fivepoint scale using one item " The total cost of finding our partner(s) was significant." To verify the existence of prior ties we asked the participants if their organization had been partnering with each other before. We used a binary variable, assigning 1 when the firms had previous partnerships with each other and 0 when no previous ties existed. Similarly, time boundedness was measured by asking participants to specify whether the duration of the partnership was agreed to be open ended, or time-restricted in terms of an agreed duration (e.g. one year), or was based on the accomplishment of set objectives (e.g. a jointly developed product). We measured strategic importance of the focal partnership for the participants' organization on a five-point scale from 1, "not important," to 5, "very important." In addition, participants were asked to consider the overall complexity of the contractual agreement taking into account the total number of provisions, as well as confidentiality and arbitration clauses rated on a scale from 1, "we made no contractual agreements," to 5, "very complex; we agreed on many provisions and took care of most uncertainties."

The dependent variable in our study is partnership culture. We applied Cameron and Quinns' (1999) Organizational Culture Assessment Instrument (OCAI) to measure the extent to which the focal innovation partnership represents a bureaucracy, market, clan or adhocracy. The OCAI has been developed to identify elements in the structure and culture of organizations; it is a suitable instrument to determine the values, beliefs and mechanisms that underlie the observable culture of the partnership. The theoretic assumptions on which the OCAI instrument is based are consistent with organization control theory. The OCAI has six dimensions: dominate characteristics, organizational leadership, management of employees, organizational glue, strategic emphasis, and criteria of success. For each of the six dimensions, participants were asked to divide 100 points 
among four alternative statements depending on the extent to which each alternative reflected the culture of their innovation partnership.

To control for other factors that could be related to partnership contracting and culture, we incorporated three control variables. First, we included a measure for the governance mode of the alliance. The involvement of shared equity in innovation partnerships is a sign of the partners' motives for and significance of the partnership (Gulati, 1995b; Oxley, 1999; Oxley \& Sampson, 2004). We measured the governance mode using a binary variable, assigning 1 to partnerships that involved the use of equity and 0 for non-equity partnerships. Second, the number of partners seeking to co-ordinate their activities might have influenced organizational culture. We therefore included a measure to assess whether the partnership was between multiple partners or two partners only. As a third control variable we measured the duration of the partnership because partners in long-lasting collaborations typically developed a mutual understanding so that impeding conflicts are less likely (Lin \& Germain, 1998; Martin, Swaminathan, \& Mitchell, 1998) and governance more flexible with mutual trust among partners. We measured duration by capturing the number of years that a partnership had been in existence at the time of measurement (Kotabe, Martin, \& Domoto, 2003; Simonin, 1999).

\subsection{Method of estimation}

To estimate the hypothesized relationships, we used Partial Least Squares (PLS-SEM) analysis with smartPLS (version 2.0 M3) (Ringle, Wende, \& Will, 2005). For an overview of the methodology see Chin (1998), Hair, Ringle, and Sarstedt (2011), Henseler, Ringle, and Sinkovics (2009), and Lohmöller (1989); and for some illustrative applications in strategic management see Birkinshaw, Morrison, and Hulland (1995), Johansson and Yip (1994), Robins, Tallman, and Fladmoe-Lindquist (2002) and Gudergan, Devinney, Richter, and Ellis (2012).

PLS-SEM is an analytical approach to situations where theory is less established and where the available variables or measures would not necessarily conform to a rigorously specified measurement model (Bagozzi \& Yi, 1994; Barclay, Higgins, \& Thompson, 1995; Fornell \& Cha, 1994; Henseler et al., 2009). This is particularly relevant given that research on contracting and culture of innovation partnerships is still in its development stage with concepts and relationships not yet empirically examined or generally accepted as a central theory. That is, the connections between 
contractual complexity, goal incongruence, and performance ambiguity on one side and the culture within innovation partnerships on the other have been relatively unexplored in prior research.

By using this methodology, we followed a growing number of researchers (Duxbury \& Higgins, 1991; House, Spangler, \& Woycke, 1991; Kahai, Sosik, \& Avolio, 1997; Sosik \& Godshalk, 2000) and expected to detect relations that might not be revealed with a more standard regression analysis method (Wilcox, 1998).

PLS-SEM has a number of other characteristics that are of advantage to our research: First, it accepts small sample sizes in order for the algorithm to work - which is important given that our samples are relatively small. Second, it does not require multivariate normality, which applies to our study. Third, it produces consistent parameter estimates; and, finally, PLS-SEM it is more suitable, compared to covariance-based methods, when measuring formative constructs, which applies to some of our constructs (Fornell \& Bookstein, 1982; Hair, Ringle, \& Sarstedt, 2012; Henseler et al., 2009; Lohmöller, 1989; Reinartz, Haenlein, \& Henseler, 2009).

\section{Results}

The hypothesized relationships and empirical estimations are illustrated in Figure 1. Before interpreting results in the structural (inner) model, we evaluate the suitability of the measures (i.e., the outer models) used to operationalize the latent variables. Based on assessing the correct specification of the measurement models, we will evaluate the predictive power of the structural model (Henseler et al., 2009), and report on the observed effects.

\subsection{Model assessment}

The overall construct reliability of multi-item scales for explanatory and dependent variables was tested by looking at the composite reliability (CR) and average variance extracted (AVE), which demonstrated satisfactory results (Fornell \& Larcker, 1981). Table 2 presents relevant CR and AVE results. The estimated indices for all constructs were above the threshold (Bagozzi, 1988) of .60 for $\mathrm{CR}$, while the indices for AVE were slightly below the threshold of .50; however, CR indices clearly exceeded the threshold value. Furthermore, the analysis of cross-loadings revealed that each item loaded higher on its respective construct than on any other construct in the model and that all constructs loaded highest with their allocated items (Chin, 1998). In Table 3 the cross-loadings are 
presented; factor loadings on respective constructs are shown in bold. To further examine discriminant validity of the complete measurement model we also tested whether the AVE measures for any two constructs that are related in the conceptual model exceeded their squared correlations (Fornell \& Larcker, 1981) and found that this condition was satisfied. Overall, the analysis of the measurement model implied discriminant validity.

\subsection{Results of the PLS Estimation}

The evaluation of the PLS structural model is typically based on three criteria: the direction and significance of the path coefficients, the effect size $\left(f^{2}\right)$, and the size of the coefficient of multiple determination $\left(\mathrm{R}^{2}\right)$ for the latent endogenous variables (Götz, Krafft, \& Liehr-Gobbers, 2005; Hulland, 1999). In what follows we present the results and interpret our findings.

Table 4 and Table 5 summarize the results of the PLS analysis. Supporting Hypothesis 1 and 2, we find that goal incongruence (GI) and performance ambiguity (PA) significantly influence contractual complexity (CC). We see partial support for Hypothesis 3, that is, contractual complexity and performance ambiguity in innovation partnerships are positively and significantly associated with bureaucracy culture (B), while the effect of goal incongruence on bureaucracy turns out to be not significant. The r-square indicates that $10 \%\left(\mathrm{R}^{2}=.103\right)$ of the variation in bureaucracy can be accounted for by the explanatory variables in the model.

Further, in support of Hypothesis 4 we find no significant effects of goal incongruence on adhocracy culture (A) and a significant negative effect of contractual complexity and performance ambiguity on adhocracy. The r-square for adhocracy $\left(\mathrm{R}^{2}=.063\right)$ indicates that only $6 \%$ of the variation in this organizational form can be accounted for by the explanatory variables in the model.

Hypothesis 5 is supported since goal incongruence is positively and significantly related to market culture (M), contractual complexity has a significant moderating effect on the relationship between goal incongruence and market-type culture, and performance ambiguity shows no significant effect. The r-square for the market culture was .134, indicating that $13 \%$ of the variation in market culture is explained by the explanatory variables in the model.

Finally, Hypothesis 6 receives partial support since goal incongruence shows the anticipated negative and significant effect on clan culture (C), and a positive effect of performance ambiguity on clans. The expected moderating effect of contractual complexity on the relationship between 
performance ambiguity and clans could not be observed. The r-square value indicates that $19 \%$ of the variation in clan culture $\left(\mathrm{R}^{2}=.187\right)$ is explained by the explanatory variables in the model.

We also analyzed the effects stemming from the included control variables. The results show that the duration of the innovation partnership (DU), the partnership mode (MO), and the number of partners (NU) also influence organizational culture. Including the control variables in our estimation, however, did not change the hypothesized effects of the core model.

Overall, the r-square results for the four latent organizational form variables in the structural model suggest a rather weak model fit (Chin, 1998), since on average about 12\% of the variation in partnership culture is explained by goal incongruence, performance ambiguity, and contractual complexity.

\section{Discussion}

The present study was an initial investigation of the relationships between the contractual complexity of partnership agreements, the goal incongruence and performance ambiguity among innovation partners as well as the consequences of these factors for the culture of innovation partnerships. Our aim was to clarify the intricacies of contractual complexity and cultures present in contemporary innovation partnerships. In what follows we discuss our findings and contribution.

\subsection{Theoretical contributions}

An important first result is that we find significant relationships of goal incongruence and performance ambiguity with contractual complexity. This result is in accordance with the theoretical relationships we proposed here and represents a first step towards understanding the intricacies of contracting and culture in innovation partnerships. The finding adds to the research that has investigated antecedent factors to complexity in partnership agreements (Ariño \& Reuer, 2006a; Reuer \& Ariño, 2007; Reuer et al., 2006) in that it indicates that goal incongruence and performance ambiguity determine contractual complexity just like the specificity of the partnership investment, the costs that are associated with finding a partner, the time boundedness of the partnership, and its strategic importance. However, the result also suggests that goal incongruence and performance ambiguity are not only antecedent to contracting arrangement between innovation partners but also 
their joint innovation culture. It, thus, provides a basis on which we can advance our understanding of the relationship between contracting and culture in innovation partnerships.

Further research is needed to better understand these relationships. For example, previous partnerships between innovation partners may correlate with reduced contractual complexity, goal incongruence and performance ambiguity among them. Organizations that repeatedly collaborate may re-use contractual provisions or negotiate a general skeleton agreement, which significantly reduces complexity of contractual provisions for the single innovation partnership. Ryall and Sampson (2006) offer some support for this effect, suggesting that when firms are engaged in multiple partnerships with the same partner, some common terms, such as arbitration clauses, are identical across all partnerships. On the other hand, a partners' perception of goal incongruence and performance ambiguity may just as likely only relate to the particular joint project at hand, where additional factors, such as risks that are associated with each new partnership (Ring \& Van de Ven, 1992) override the possible reducing effect.

The central result of our study, however, is that it provides strong support for a fundamental role and the influence of contractual complexity on the emergent culture of innovation partnerships. Although not all relationships in the model estimation clearly support the hypothesized effects on bureaucracy, market, clan, and adhocracy cultures, we can account for a strong and significant influence of contractual complexity on the culture of innovation partnerships. Thus, with increasing levels of contractual complexity, culture in innovation partnerships takes on the characteristics of a bureaucracy, following the relationships proposed here based on organizational control theory. Given that the governance mechanisms underlying bureaucracy culture are typically subject to contractual provisions (e.g. Reuer \& Ariño, 2003; Reuer et al., 2006; Sampson, 2004) we find evidence of complexity of contracts between these partnering organizations.

Adhocracy, on the other hand, showed a significant negative relationship with contractual complexity, which confirms our prediction that complex contractual agreements are rare within adhocracies due to intensive but informal interaction, spontaneity, casualness, and interpersonal familiarity among team members (Jarillo, 1988). Finally, for market and clan cultures we also find that the level of contractual complexity influences their development, that is, high levels of contractual complexity support market and inhibit clan cultures. This is in accordance with our prediction; in particular, in conjunction with the result that contractual complexity moderates the 
effect of goal incongruence in case of market cultures and the insignificance of performance ambiguity as an antecedent of market culture.

While we showed how aspects of contractual complexity and partnership culture relate to uncertainties about goals and mutual performance among innovation partners, it would be especially fruitful to understand whether these influences occur simultaneously or if they are sequential. Likewise, further investigation of the causality of these relationships would reveal potentially interesting results. Hence additional longitudinal and case research is needed where sequence and causality of these influences on the development of partnership cultures can be observed.

Even though the existing literature suggests that contracting and governance in alliances are interrelated (Ariño \& Reuer, 2006a) and that governance in collaborations occurs with contractual heterogeneity (Lerner \& Merges, 1998; Reuer \& Ariño, 2003), the specific relationships between such factors remain vague. In this study we contributed to further clarifying the role and influence of contractual complexity in conjunction with the effects of goal incongruence and performance ambiguity on the type of culture that emerges in innovation partnerships. In doing so we add to a body of literature that suggests a range of aspects - like asset specificity, partner search costs, prior ties, alliance time boundedness, strategic importance, firm age (Reuer \& Ariño, 2002; 2003; 2007; 2006), technology scope and transactions activities (Oxley, 1997; Pisano, 1989), technological change, and performance measurement difficulty (Poppo \& Zenger, 2002) - influence contracts, governance and culture of partnership. Along those lines we also suggest that contractual complexity and partnership culture share antecedent factors, which contributes to the organizational control perspective by expanding on the existing conjecture that goal incongruence and performance ambiguity alone determine partnership culture. Hence, in inter-organizational situations the contractual complexity among partners is a third formative and significant dimension to consider. This contribution is important because it emphasizes the limitation of present organizational control theory in explaining inter-organizational culture and because it provides the basis for a more comprehensive perspective that includes contractual complexity. Our work also contributes to the contracting literature in that it further clarifies the central role of contractual complexity as a suitable and relevant concept to capture the nature of an inter-organizational relationship and its importance for understanding emerging innovation culture in partnership situations. 


\subsection{Managerial implication}

From a managerial perspective our study results show how important it is for innovation partners to better understand what the underlying factors of contractual agreements and governance mechanisms are particularly when aiming for specific innovation outcomes. The firm's ability to negotiate partnership contracts is influenced by a range of factors which, when explicit and better understood, can help the partners avoid unnecessarily complex agreements or, on the other hand, include crucial contractual agreements to safeguard against the unwanted actions of partners and innovation team members.

In addition, our findings offer some interesting suggestions for the harmonization of partnership contracts and innovation partnership culture. While we find that different levels of goal incongruence, performance ambiguity, and contractual complexity establish certain cultures, we suppose it is also practical to plan governance and culture for a focal innovation partnership by intentionally reducing contractual complexity. That is, in situations where the partnership requires a high level of sovereignty, creative freedom, and autonomy, for example in the case of R\&D partnerships or skunkwork projects, (Bommer, DeLaPorte, \& Higgins, 2002) innovation partners should avoid high contractual complexity with restrictive and controlling enforcement provisions. Hence, while accounting for the relationships proposed here, that is assessing the goal incongruence and performance ambiguity and managing the complexity of the partnership contract, firms would be able to identify and employ partnership cultures that better support their strategic intentions and ultimately benefit their joint and individual performance. Consequently, the ability to negotiate and manage the complexity of alliance contracts becomes critical for innovation partners. We suggest that upcoming research on alliance contracts should examine this ability as a dynamic capability in collaborative innovation formation and management (Mayer \& Argyres, 2004).

\subsection{Limitations and direction for future research}

A limitation of our framework and this study is that it rests on restricted theoretical assumptions. Even though we focus on organizational control theory, there might be other aspects of partnership contracting and management that are important to consider. For example, Ring and Van de Vens' (1994) process perspective of alliance contracting implies an influence of a psychological contract on the behavioral uncertainty that the contracting parties face once they are partners. The 
psychological contract goes beyond and may complement or substitute the agreement of a legal document. In their framework, contracting is a part of the commitment stage of collaborations where mutual consent is achieved by a process of sense making, which occurs when the parties interact intensively. The parties assess their possible compatibility and develop opinions about each other which can result in a psychological contract (Ring \& Van de Ven, 1994). The role and influence of the psychological contract have not been considered in our framework. We suggest that upcoming conceptual and empirical studies include psychological contracts when discussing the relationships between contracting and culture in innovation partnerships.

Another theoretical perspective that we have not considered here and which has in general not been considered much in the field of partnership management and governance is the organizational behavior perspective (Ariño \& Reuer, 2006b). Future research could, for example, look at the implications of the relationships proposed in this study and examine how they relate to other innovation management and collaboration phenomena such as various types of behavioral dynamics at the individual or group level, process dimensions of collaboration, and the organizational and managerial context of partnership formation and management including managerial capabilities, leadership behavior, and the functioning of teams within and across organizations. Hence, expanding on the model presented here offers a plethora of additional research opportunities.

\section{References}

Achrol, R. S. 1997. Changes in the Theory of Interoganisational Relations in Marketing: Toward a Network Paradigm. Journal of the Academy of Marketing Science, 25(1): 56-71.

Adams, R., Bessant, J., \& Phelps, R. 2006. Innovation management measurement: A review. International Journal of Management Reviews, 8(1): 21-47.

Ahmed, P. K. 1998. Culture and climate for innovation. European journal of innovation management, 1(1): 30-43.

Alchian, A. A., \& Demsetz, H. 1972. Production, information costs, and economic organization. American Economic Review, 62(5): 777-795.

Anderson, E., \& Weitz, B. A. 1992. The Use of Pledges to Build and Sustain Commitment in Distribution Channels. Journal of Marketing Research, 29: 18-34.

Argyres, N. S., Bercovitz, J., \& Mayer, K. J. 2007. Complementarity and Evolution of Contractual Provisions: An Empirical Study of IT Services Contracts. Organization Science, 18(1): 3-19. 
Ariño, A., \& Reuer, J. J. 2006a. Alliance Contractual Design. In O. Shenkar, \& J. J. Reuer (Eds.), Handbook of strategic alliances: 149-167. Thousand Oaks: Sage Publications.

Ariño, A., \& Reuer, J. J. 2006b. Introduction: Governance and Contracts in Strategic Alliances. In A. Ariño, \& J. J. Reuer (Eds.), Strategic Alliances: Governance and Contracts. London, UK: Palgrave.

Armstrong, J. S., \& Overton, D. 1977. Estimating nonresponse bias in mail surveys. Journal of Marketing Research, 14(3): 396-402.

Bagozzi, R. P. 1988. The rebirth of attitude research in marketing. Journal of the Market Research Society, 30(2): 163-195.

Bagozzi, R. P., \& Yi, Y. 1994. Advanced topics in structural equation models. In R. P. Bagozzi (Ed.), Advanced Methods of Marketing Research: 1-52. Cambridge, MA: Blackwell.

Barclay, D., Higgins, C., \& Thompson, R. 1995. The Partial Least Squares (PLS) Approach to Causal Modeling: Personal Computer Adoption and Use as an Illustration. Technology Studies, 2(2): 285-309.

Barzel, Y. 1982. Measurement costs and the organization of markets. Journal of Law and Economics, 25 27-48.

Bernheim, B. D., \& Whinston, M. D. 1998. Incomplete contracts and strategic ambiguity. The American Economic Review, 88(4): 902-932.

Birkinshaw, J., Morrison, A., \& Hulland, J. 1995. Structural and competitive determinants of a global integration strategy. Strategic Management Journal, 16(8): 637-655.

Bommer, M., DeLaPorte, R., \& Higgins, J. 2002. Skunkworks approach to project management. Journal of Management in Engineering, 18(1): 21-28.

Bryant, A., \& Colledge, B. 2002. Trust in Electronic Commerce Business Relationships. Journal of Electronic Commerce Research, 3(2): 32-39.

Cameron, K. S., \& Ettington, D. R. 1988. Conceptual foundations of organizational culture. In J. C. Smart (Ed.), Higher education: handbook of theory and research, Vol. 4: 356-396. New York: Agathon Press.

Cameron, K. S., \& Quinn, R. E. 1999. Diagnosing and changing organizational culture. Upper Saddle River, NJ: Prentice-Hall.

Cameron, K. S., \& Quinn, R. E. 2011. Diagnosing and changing organizational culture: Based on the competing values framework: John Wiley \& Sons.

Chin, W. W. 1998. The Partial Least Squares Approach for Structural Equation Modelling. In G. A. Marcoulides (Ed.), Modern Methods of Business Research: 295-336. Mahwan, NJ:

Lawrence Erlbaum Associates. 
Daft, R. L. 1995. Organization theory and design (5th ed.). Minneapolis, St. Paul: West Publishing Company.

Demsetz, H. 1988. The theory of the firm revisited. Journal of Law, Economics, and Organization, 4: 141-162.

DeVellis, R. F. 1991. Scale Development: Theory and Applications. Newbury Park, CA: Sage Publications.

DiTomaso, N. 1987. Symbolic media and social solidarity: The foundations of corporate culture. Research in the Sociology of Organizations, 5: 105-134.

Doz, Y. L. 1996. The Evolution of Cooperation in Strategic Alliances: Initial Conditions or Learning. Strategic Management Journal, 17: 55-83.

Doz, Y. L., Olk, P. M., \& Ring, P. 2000. Formation Processes of R\&D Consortia: Which Path to take? Where does it lead? Strategic Management Journal, 21: 239-266.

Duncan, W. J. 1989. Organizational culture:"Getting a fix” on an elusive concept. The Academy of Management Executive, 3(3): 229-236.

Duxbury, R. M., \& Higgins, C. A. 1991. Gender differences in work-family conflict. Journal of Applied Psychology, 76: 60-74.

Eisenhardt, K. 1985. Control: organizational and economic approaches. Management Science, 31(2): 134-149.

Fornell, C., \& Bookstein, F., L. 1982. Two structural equation models: LISREL and PLS applied to consumer exit-voice theory. JMR, Journal of Marketing Research (pre-1986), 19(4): 440.

Fornell, C., \& Cha, J. 1994. Partial Least Squares. In R. P. Bagozzi (Ed.), Advanced Methods in Marketing Research. Oxford: Blackwell.

Fornell, C., \& Larcker, D. F. 1981. Evaluating Structural Equation Models with Unobservable Variables and Measurement Error. Journal of Marketing Research, 18(1): 39-50.

Gerwin, D., \& Ferris, J. S. 2004. Organizing New Product Development Projects in Strategic Alliances. Organization Science, 15(1): 22-38.

Goldberg, V. 1976. Towards an Expanded Economic Theory of Contract. Journal of Economic Issues, 10: 45-61.

Götz, O., Krafft, M., \& Liehr-Gobbers, K. 2005. Evaluation of Structural Equation Models using the Partial Least Squares Approach. Paper presented at the PLS'05 International Symposium, Barcelona, Spain.

Gudergan, S. P., Devinney, T., Richter, N. F., \& Ellis, R. S. 2012. Strategic Implications for (NonEquity) Alliance Performance. Long Range Planning, 45(5-6): 451-476. 
Gulati, R. 1995a. Does familiarity breed trust? The implications of repeated ties for contractual choice in alliances. Academy of Management Journal, 38(1): 85-112.

Gulati, R. 1995b. Social structure and alliance formation pattern: A longitudinal analysis. Administrative Science Quarterly, 40: 619-642.

Gulati, R. 1998. Alliances and Networks. Strategic Management Journal, 19: 293-317.

Gulati, R., \& Singh, H. 1998. The architecture of cooperation: Managing coordination costs and appropriation concerns in strategic alliances. Administrative Science Quarterly, 43(4): 781815.

Hair, J. F., Ringle, C. M., \& Sarstedt, M. 2011. PLS-SEM: Indeed a silver bullet. The Journal of Marketing Theory and Practice, 19(2): 139-152.

Hair, J. F., Ringle, C. M., \& Sarstedt, M. 2012. Partial Least Squares: The Better Approach to Structural Equation Modeling? Long Range Planning, 45(5-6): 312-319.

Heide, J. B. 1994. Interorganisational Governance in Marketing Channels. Journal of Marketing, 58: 71-85.

Heimeriks, K. H., Duysters, G., \& Vanhaverbeke, W. 2005. Developing Alliance Capabilties: An Empirical Study. Paper presented at the Academy of Management Conference, Honolulu, USA.

Hennart, J.-F. 1988. A transaction cost theory of equity joint ventures. Strategic Management Journal, 9(4): 361-374.

Henseler, J., Ringle, C. M., \& Sinkovics, R. R. 2009. The use of partial least squares path modeling in international marketing. Advances in international marketing, 20(1): 277-319.

Hoetker, G., \& Mellewigt, T. 2009. Choice and performance of governance mechanisms: matching alliance governance to asset type. Strategic Management Journal, 9999(9999): n/a.

House, R. J., Spangler, W. D., \& Woycke, J. 1991. Personality and charisma in the U.S. presidency: a psychological theory of leader effectiveness. Administrative Science Quarterly, 36: 364396.

Hulland, J. 1999. Use of Partial Least Squares (PLS) in Strategic Management Research: A review of four recent studies. Strategic Management Journal, 20: 195-204.

Inkpen, A. C., \& Crossan, M. M. 1995. Believing Is Seeing: Joint Ventures and Organization Learning*. Journal of Management Studies, 32(5): 595-618.

Isaksen, S. G., Lauer, K. J., Ekvall, G., \& Britz, A. 2001. Perceptions of the best and worst climates for creativity: Preliminary validation evidence for the situational outlook. Creativity Research Journal, 13: 171-184. 
Jarillo, J. C. 1988. On Strategic Networks. Strategic Management Journal, 9(1): 31-41.

Jeffries, F. L., \& Reed, R. 2000. Trust and adaptation in relational contracting. Academy of Management Review, 25(4): 873-883.

Johansson, J. K., \& Yip, G. S. 1994. Exploiting globalization potential: U.S. and Japanese strategies. Strategic Management Journal, 15(8): 579-601.

John, G., \& Reve, T. 1982. The Reliability and Validity of Key Informant Data from Dyadic Relationships in Marketing Channels. Journal of Marketing Research, 19(4): 517-524.

Kahai, S. S., Sosik, J. J., \& Avolio, B. J. 1997. Effects of leadership style and problem structure on work group process and outcomes in an electronic meeting system environment. Personnel Psychology, 50: 121-146.

Kale, P., Dyer, J. H., \& Singh, H. 2002. Alliance Capability, Stock Market Response, and LongTerm Alliance Success: The Role of the Alliance Function. Strategic Management Journal, 23(8): 747-767.

Kale, P., Singh, H., \& Perlmutter, H. 2000. Learning and protection of proprietary assets in strategic alliances: building relational capital. Strategic Management Journal, 21(3): 217-237.

Kanuk, L., \& Berenson, C. 1975. Mail surveys and response rates: a literature review. Journal of Marketing Research, 12: 440-453.

Kotabe, M., Martin, X., \& Domoto, H. 2003. Gaining from vertical partnerships: Knowledge transfer, relationship duration, and supplier performance improvement in the U.S. and Japanese automotive industries. Strategic Management Journal, 24(4): 293-316.

Krishnan, R., Martin, X., \& Noorderhaven, N. G. 2006. When does trust matter to alliance performance? Academy of Management Journal, 49(5): 894-917.

Kumar, N., Stern, L. W., \& Anderson, J. C. 1993. Conducting interorganizational research using key informants. Academy of Management Journal, 36(6): 1633-1651.

Lane, P. J., Salk, J. E., \& Lyles, M. A. 2001. Absorptive Capacity, Learning, and Performance in international Joint Ventures. Strategic Management Journal, 22(12): 1139-1161.

Lee, C.-K., Tan, B., \& Chiu, J.-Z. 2008. The impact of organisational culture and learning on innovation performance. International Journal of Innovation and Learning, 5(4): 413-428.

Lee, S. M., Olson, D. L., \& Trimi, S. 2010. Strategic innovation in the convergence era. International Journal of Management and Enterprise Development, 9(1): 1-12.

Lerner, J., \& Merges, R. P. 1998. The control of technology alliances: An empirical analysis of the biotechnology industry. Journal of Industrial Economics, 46: 125-156. 
Lin, X., \& Germain, R. 1998. Sustaining satisfactory joint venture relationships: The role of conflict resolution strategy. Journal of International Business Studies, 29: 179-196.

Linnarsson, H., \& Werr, A. 2004. Overcoming the innovation-alliance paradox: a case study of an explorative alliance. European Journal of Innovation Management, 7(1): 45-55.

Lohmöller, J. B. 1989. Latent variable path modeling with partial least squares: Physica-Verlag Heidelberg.

Lui, S. S., \& Ngo, H.-Y. 2004. The Role of Trust and Contractual Safeguards on Cooperation in Non-equity Alliances. Journal of Management, 30(4): 471-485.

Luo, Y. 2002. Contract, cooperation, and performance in international joint ventures. Strategic Management Journal, 23(10): 903-919.

Luo, Y., \& Tan, J. 2003. Structuring international joint ventures: how should contractual design be aligned with environmental conditions? Management International Review, 43(2): 185-211.

Macaulay, S. 1963. Non contractual relations in business: A preliminary study. The American Economic Review, 28 (1): 55-69.

Macneil, I. R. 1978. Contracts: Adjustment of Long-term Economic Relations Under Classical, Neoclassical and Relational Contract Law. Northwestern University Law Review, 72: 854905.

Martin, X., Swaminathan, A., \& Mitchell, W. 1998. Organizational evolution in the interorganizational environment: Incentives and constraints on international expansion strategy. Administrative Science Quarterly, 43(3): 566-601.

Mayer, K. J., \& Argyres, N. S. 2004. Learning to contract: Evidence from the personal computer industry. Organization Science, 15(4): 394-410.

Mintzberg, H. 1979. The structuring of organizations. Englewood Cliffs, NJ: Prentice-Hall.

Mintzberg, H. 1993. Structure in fives. Designing effective organizations. Englewood Cliffs, NJ: Prentice-Hall.

Mohr, J., \& Spekman, R. 1994. Characteristics of partnership success: partnership attributes, communication behavior and conflict resolution. Strategic Management Journal, 15(2): $135-152$.

Nielsen, B. B. 2003. An Empirical Investigation of the Drivers of International Strategic Alliance Formation. European Management Journal, 21(3): 301-322.

Nooteboom, B., Berger, H., \& Noorderhaven, N. G. 1997. Effects of trust and governance on relational risk. Academy of Management Journal, 40(2): 308-339. 
O'Reilly, C. 1989. Corporations, Culture, and Commitment: Motivation and Social Control in Organizations. California Management Review, 31(4): 9-25.

Osborn, R. N., \& Baughn, C. C. 1990. Forms of Interorganizational Governance for Multinational Alliances. Academy of Management Journal, 33(3): 503-519.

Ouchi, W. G. 1979. A conceptual framework for the design of organizational control mechanisms. Management Science, 25(9): 833-848.

Ouchi, W. G. 1980. Markets, Bureaucracies, and Clans. Administrative Science Quarterly, 25(1): 129-141.

Oxley, J. E. 1997. Appropriability hazards and governance in strategic alliances: A transaction cost approach. Journal of Law, Economics and Organization, 13(2): 387-409.

Oxley, J. E. 1999. Institutional environment and the mechanisms of governance: the impact of intellectual property protection on the structure of inter-firm alliances. Journal of Economic Behavior and Organization, 38(3): 283-309.

Oxley, J. E., \& Sampson, T. C. 2004. The Scope and Governance of International R\&D Alliances. Strategic Management Journal, 25(8-9): 723-749.

Philips, L. 1981. Assessing measurement error in key informant reports: a methodological note on organizational analysis in marketing. Journal of Marketing Research 18(4): 395-415.

Pisano, G. 1989. Using equity participation to support exchange: Evidence from the biotechnology industry. Journal of Law, Economics and Organization, 5(1): 109-126.

Podsakoff, P. M., MacKenzie, S. B., Jeong-Yeon, L., \& Podsakoff, N. P. 2003. Common Method Biases in Behavioral Research: A Critical Review of the Literature and Recommended Remedies. Journal of Applied Psychology, 88(5): 879.

Poppo, L., \& Zenger, T. 2002. Do formal contracts and relational governance function as substitutes or complements? Strategic Management Journal, 23(8): 707-725.

Quinn, R. E., Hildebrandt, H. W., Rogers, P. S., \& Thompson, M. P. 1991. A competing values framework for analyzing presentational communication in management contexts. Journal of Business Communication, 28(3): 213-232.

Quinn, R. E., \& Rohrbaugh, J. 1981. A Competing Values Approach to Organizational Effectiveness. Public Productivity Review, 5(2): 122-140.

Reinartz, W., Haenlein, M., \& Henseler, J. 2009. An empirical comparison of the efficacy of covariance-based and variance-based SEM. International Journal of Research in Marketing, 26(4): 332-344.

Reuer, J. J., \& Ariño, A. 2002. Contractual Renegotiations in Strategic Alliances. Journal of Management, 28(1): 47-68. 
Reuer, J. J., \& Ariño, A. 2003. Strategic alliances as contractual forms. Paper presented at the Academy of Management (AoM), Seatle, USA.

Reuer, J. J., \& Ariño, A. 2007. Strategic alliance contracts: dimensions and determinants of contractual complexity. Strategic Management Journal, 28(3): 313-330.

Reuer, J. J., Ariño, A., \& Mellewigt, T. 2006. Entrepreneurial Alliances as Contractual Forms. Journal of Business Venturing, 21(3): 306-325.

Reuer, J. J., Park, K. M., \& Zollo, M. 2002. Experiential learning in international joint ventures: The roles of experience heterogeneity and venture novelty. In F. J. Contractor, \& P. Lorange (Eds.), Cooperative Strategies and Alliances: 321-344. Oxford: Elsevier Science.

Reuer, J. J., Zollo, M., \& Singh, H. 2002. Post-formation dynamics in strategic alliances. Strategic Management Journal, 23(2): 135-151.

Ring, P., \& Van de Ven, A. 1994. Developmental Processes of Cooperative Interorganizational Relationships. Academy of Management Review, 19(1): 90-118.

Ring, P., \& Van de Ven, A. H. 1992. Structuring Cooperative Relationships Between Organizations. Strategic Management Journal, 13(7): 483-498.

Ringle, C. M., Wende, S., \& Will, A. 2005. SmartPLS - Version 2.0. Hamburg: Universität Hamburg.

Robins, J. A., Tallman, S., \& Fladmoe-Lindquist, K. 2002. Autonomy and dependence of international cooperative ventures: an exploration of the strategic performance of U.S. ventures in Mexico. Strategic Management Journal, 23(10): 881-901.

Ryall, M. D., \& Sampson, R. C. 2006. Do Prior Alliances Influence Alliance Contract Structure? In A. Ariño, \& J. J. Reuer (Eds.), Strategic Alliances: Governance and Contracts. London, UK: Palgrave.

Sampson, R. C. 2004. The Cost of Misaligned Governance in R\&D Alliances. Journal of Law Economics \& Organization, 20(2): 484-526.

Schein, E. H. 2010. Organizational culture and leadership: John Wiley \& Sons.

Schumpeter, J. A. 1934. The theory of economic development: an enquiry into profits, capital, credit, interest and the business cycle. Cambridge, Mass.: Harvard University Press.

Scott, W. R. 1998. Organizations: Rational, natural, and open systems. Upper Saddle River, NJ: Prentice Hall, Inc.

Simonin, B. L. 1997. The importance of collaborative Know-How: An empirical test of the learning organization. Academy of Management Journal, 40(5): 1150-1174. 
Simonin, B. L. 1999. Ambiguity and the process of knowledge transfer in strategic alliances. Strategic Management Journal, 20(7): 595-623.

Sosik, J. J., \& Godshalk, V. M. 2000. Leadership styles, mentoring functions received, and jobrelated stress: a conceptual model and preliminary study. Journal of Organizational Behavior, 21(4): 365-390.

Stump, R. L., \& Heide, J. B. 1996. Controlling supplier opportunism in industrial relationships. Journal of Marketing Research, 33(4): 431-442.

Tapscott, D., \& Williams, A. D. 2008. Wikinomics: How mass collaboration changes everything: Penguin. com.

White, S., \& Lui, S.-Y. S. 2005. Distinguishing costs of cooperation and control in alliances. Strategic Management Journal, 26(10): 913-932.

Wilcox, R. R. 1998. How many discoveries have been lost by ignoring modern statistical methods? American Psychologist, 53: 300-314.

Williamson, O. E. 1975. Market and Hierarchies: Analysis and Antitrust Implications. New York: Free Press.

Williamson, O. E. 1985. The Economic Institution of Capitalism. New York: Free Press.

Williamson, O. E. 1991. Comparative economic organization: The analysis of discrete structural alternatives. Administrative science quarterly: 269-296.

Zaheer, A., McEvily, B., \& Perrone, V. 1998. Does Trust Matter? Exploring the Effects of Interorganizational and Interpersonal Trust on Performance. Organization Science, 9(2): 141-159.

Zammuto, R. F., \& Krakower, J. Y. 1991. Quantitative and qualitative studies of organizational culture: JAI Press Inc.

Zenger, T. R., \& Hesterly, W. S. 1997. The disaggregation of corporations: Selective intervention, high-powered incentives, and molecular units. Organization Science, 8(3): 209-222.

Zollo, M., Reuer, J. J., \& Singh, H. 2002. Interorganizational Routines and Performance in Strategic Alliances. Organization Science, 13(6): 701-713. 


\section{Appendix}

Figure 1: Structural model and hypotheses

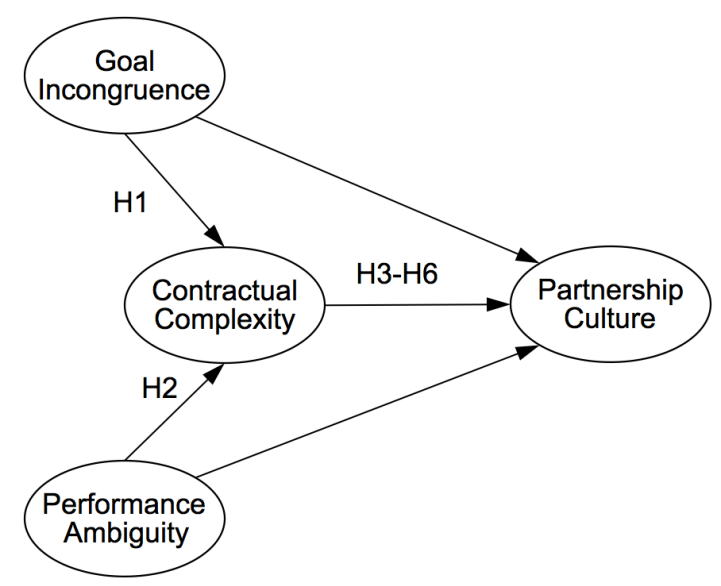


Table 1: Survey items

\section{Construct Item/Scale}

Goal (1) The partnering organizations have consistent objectives (reverse coded). (2) The

Incongruence (GI) strategic goals of partners are in harmony (reverse coded).

Performance (1) It is unclear how we can assess the performance of our partner(s). (2) It is difficult to

Ambiguity (PA) know whether our partner(s) do what they agreed upon.

Contractual

Complexity (CC)
(1) We spend substantial effort and money on infrastructure that is dedicated exclusively to this partnership. (2) The total cost of finding our partner(s) was significant. (3) Did your organization have alliances with one or more of the partners prior to this one? (4) What is the agreement among partners regarding the duration of the partnership? (5) How do you rate the overall strategic importance of this partnership to your organization in general at the present time? (6) When considering the contractual agreement between your organization and your partner(s), and taking into account the total number of provisions, confidentiality clauses or arbitration clauses, etc., how complex is the contractual agreement?

Adhocracy (A) $\quad$ (1) This alliance is a very dynamic and entrepreneurial place. People are willing to stick their necks out and take risks. (2) The leadership in this alliance is generally considered to exemplify entrepreneurship, innovating, or risk taking. (3) The management style in this alliance is characterized by individual risk-taking, innovation, freedom, and uniqueness.

(4) The glue that holds the alliance together is commitment to innovation and development. There is an emphasis on being on the cutting edge. (5) This alliance emphasizes acquiring new resources and creating new challenges. Trying new things and prospecting for opportunities are valued. (6) This alliance defines success on the basis of having the most unique or newest products. It is a product leader and innovator.

Bureaucracy (B) (1) This alliance is a very controlled and structured place. Formal procedures generally govern what people do. (2) The leadership in this alliance is generally considered to exemplify coordinating, organizing, or smooth-running efficiency. (3) The management style in this alliance is characterized by security of employment, conformity, predictability, and stability in relationships. (4) The glue that holds the alliance together is formal rules and policies. Maintaining a smooth-running alliance is important. (5) This alliance emphasizes permanence and stability. Efficiency, control and smooth operations are important. (6) This alliance defines success on the basis of efficiency. Dependable delivery, smooth scheduling and low-cost production are critical.

Clan (C) (1) This alliance is a very personal place. It is like an extended family. People seem to share a lot of themselves. (2) The leadership in this alliance is generally considered to exemplify mentoring, facilitating, or nurturing. (3) The management style in this alliance is characterized by teamwork, consensus, and participation. (4) The glue that holds the alliance together is loyalty and mutual trust. Commitment to this alliance runs high. (5) This alliance emphasizes human development. High trust, openness, and participation persist. (6) This alliance defines success on the basis of the development of human resources, teamwork, employee commitment, and concern for people.

\section{Market (M)}

(1) This alliance is a very results oriented. A major concern is with getting the job done. People are very competitive and achievement oriented. (2) The leadership in this alliance is generally considered to exemplify a no-nonsense, aggressive, results-oriented focus. (3) The management style in this alliance is characterized by hard-driving competitiveness, high demands, and achievement. (4) The glue that holds the alliance together is the emphasis on achievement and goal accomplishment. Aggressiveness and winning are common themes. (5) This alliance emphasizes competitive actions and achievement. Hitting stretch targets and winning in the marketplace are dominant. (6) This alliance defines success on the basis of winning in the marketplace and outpacing the competition. Competitive market leadership is key. 
Table 2: Indicator and construct reliability

\begin{tabular}{lccc} 
Construct & Items & AVE & CR \\
\hline Goal Incongruence (GI) & 2 & .77 & .87 \\
Performance Ambiguity (PA) & 2 & .75 & .85 \\
Contractual Complexity (CC) & 6 & .62 & .76 \\
Adhocracy (A) & 6 & .40 & .80 \\
Bureaucracy (B) & 6 & .48 & .68 \\
Clan (C) & 6 & .49 & .85 \\
Market (M) & 6 & .47 & .84
\end{tabular}

Table 3: Cross-loadings of measurement items

\begin{tabular}{|c|c|c|c|c|c|c|c|}
\hline Item & $\mathbf{C C}$ & GI & PA & $\mathbf{A}$ & B & $\mathbf{C}$ & $\mathbf{M}$ \\
\hline cc1 & .57 & .11 & .32 & .14 & .10 & .11 & .05 \\
\hline $\operatorname{cc} 2$ & .78 & .04 & .37 & .21 & .11 & .24 & .15 \\
\hline $\operatorname{cc} 3$ & .22 & .14 & .08 & .05 & .02 & .00 & .03 \\
\hline $\operatorname{cc} 4$ & .28 & .01 & .06 & .00 & .12 & .15 & .07 \\
\hline $\operatorname{cc} 5$ & .14 & .07 & .03 & .01 & .01 & .10 & .13 \\
\hline $\operatorname{cc} 6$ & .67 & .00 & .04 & .06 & .24 & .37 & .26 \\
\hline gi1 & .14 & .73 & .15 & .01 & .05 & .08 & .09 \\
\hline gi2 & .05 & .88 & .19 & .02 & .12 & .18 & .25 \\
\hline pa1 & .19 & .17 & .72 & .09 & .20 & .07 & .04 \\
\hline pa2 & .27 & .28 & .91 & .14 & .26 & .25 & .12 \\
\hline a1 & .10 & .07 & .01 & .59 & .27 & .03 & .08 \\
\hline $\mathrm{a} 2$ & .08 & .06 & .05 & .50 & .10 & .09 & .04 \\
\hline a3 & .20 & .03 & .11 & .70 & .11 & .12 & .04 \\
\hline a4 & .11 & .08 & .10 & .78 & .09 & .15 & .13 \\
\hline a5 & .05 & .10 & .05 & .55 & .10 & .07 & .11 \\
\hline a6 & .16 & .02 & .13 & .69 & .02 & .17 & .03 \\
\hline $\mathrm{b} 1$ & .16 & .07 & .11 & .26 & .70 & .33 & .11 \\
\hline b2 & .12 & .12 & .10 & .22 & .34 & .08 & .31 \\
\hline b3 & .07 & .00 & .17 & .16 & .49 & .20 & .21 \\
\hline b4 & .11 & .03 & .15 & .27 & .67 & .36 & .07 \\
\hline b5 & .02 & .06 & .02 & .22 & .47 & .25 & .08 \\
\hline b6 & .05 & .05 & .10 & .23 & .42 & .12 & .19 \\
\hline $\mathrm{c} 1$ & .26 & .04 & .11 & .03 & .33 & .65 & .45 \\
\hline $\mathrm{c} 2$ & .10 & .11 & .02 & .02 & .06 & .50 & .44 \\
\hline c3 & .35 & .14 & .25 & .25 & .43 & .73 & .51 \\
\hline $\mathrm{c} 4$ & .30 & .12 & .22 & .15 & .38 & .79 & .47 \\
\hline$c 5$ & .19 & .13 & .09 & .04 & .23 & .76 & .56 \\
\hline c6 & .15 & .13 & .01 & .05 & .09 & .64 & .51 \\
\hline $\mathrm{m} 1$ & .01 & .02 & .00 & .18 & .20 & .34 & .39 \\
\hline $\mathrm{m} 2$ & .14 & .18 & .08 & .22 & .36 & .49 & .71 \\
\hline $\mathrm{m} 3$ & .24 & .15 & .09 & .02 & .17 & .64 & .83 \\
\hline $\mathrm{m} 4$ & .18 & .17 & .04 & .12 & .12 & .49 & .70 \\
\hline $\mathrm{m} 5$ & .21 & .13 & .04 & .09 & .03 & .46 & .73 \\
\hline $\mathrm{m} 6$ & .07 & .15 & .01 & .10 & .08 & .36 & .65 \\
\hline
\end{tabular}


Table 4: PLS estimation results for structural model

\begin{tabular}{|c|c|c|c|}
\hline \multirow{2}{*}{\multicolumn{2}{|c|}{ Hypotheses (Proposed effect) }} & \multicolumn{2}{|c|}{$\mathrm{N}=289$} \\
\hline & & Path Coefficient $f^{2}$ & $\begin{array}{l}\text { t-statistic } \\
\text { (p-value) }\end{array}$ \\
\hline \multicolumn{4}{|c|}{ Effects of Goal Incongruence and Performance Ambiguity } \\
\hline$H 1:$ & $\mathrm{GI} \rightarrow \mathrm{CC}(+)$ & .21 & $3.32 * *(.0204)$ \\
\hline H2: & $\mathrm{PA} \rightarrow \mathrm{CC}(+)$ & .38 & $7.56^{* *}(.0000)$ \\
\hline \multicolumn{4}{|c|}{ Effects of Contractual Complexity } \\
\hline \multirow[t]{3}{*}{ H3: } & $\mathrm{GI} \rightarrow \mathrm{B}$ & .10 & $.76(.4478)$ \\
\hline & $\mathrm{CC} \rightarrow \mathrm{B}$ & .24 & $3.37 * *(.3178)$ \\
\hline & $\mathrm{PA} \rightarrow \mathrm{B}$ & .21 & $2.70 * *(.1751)$ \\
\hline \multirow[t]{3}{*}{ H4: } & $\mathrm{GI} \rightarrow \mathrm{A}$ & -.02 & $.47(.6351)$ \\
\hline & $\mathrm{CC} \rightarrow \mathrm{A}$ & -.10 & $2.45 *(.0145)$ \\
\hline & $\mathrm{PA} \rightarrow \mathrm{A}$ & -.17 & $2.31 *(.0208)$ \\
\hline \multirow[t]{5}{*}{ H5: } & $\mathrm{GI} \rightarrow \mathrm{M}$ & .19 & $3.01 * *(.0026)$ \\
\hline & $\mathrm{CC} \rightarrow \mathrm{M}$ & .24 & $5.35^{* *}(.0000)$ \\
\hline & $\mathrm{PA} \rightarrow \mathrm{M}$ & .01 & $.66(.5089)$ \\
\hline & $\mathrm{GI} \times \mathrm{CC} \rightarrow \mathrm{M}$ & .18 & $3.43 * *(.0161)$ \\
\hline & $\mathrm{PA} \times \mathrm{CC} \rightarrow \mathrm{M}$ & .13 & $.77(.0048)$ \\
\hline \multirow[t]{5}{*}{ H6: } & $\mathrm{GI} \rightarrow \mathrm{C}$ & -.13 & $2.30 *(.2310)$ \\
\hline & $\mathrm{CC} \rightarrow \mathrm{C}$ & -.36 & $6.45^{* *}(.0000)$ \\
\hline & $\mathrm{PA} \rightarrow \mathrm{C}$ & .15 & $5.61^{* *}(.0000)$ \\
\hline & $\mathrm{GI} \times \mathrm{CC} \rightarrow \mathrm{C}$ & -.01 & $1.62 \dagger(.0967)$ \\
\hline & $\mathrm{PA} \times \mathrm{CC} \rightarrow \mathrm{C}$ & -.21 & $.99(.0048)$ \\
\hline \multicolumn{4}{|c|}{ Effects of control variables } \\
\hline Dura & f partnership DU $\rightarrow$ B & -.01 & $.51(0.0021)$ \\
\hline Dura & f partnership DU $\rightarrow M$ & -.09 & $2.74 *(0.0005)$ \\
\hline Dura & f partnership DU $\rightarrow C$ & .15 & $3.38 * *(0.0008)$ \\
\hline Dura & f partnership DU $\rightarrow A$ & .13 & $2.11 *(0.0006)$ \\
\hline Gove & mode $\mathrm{MO} \rightarrow \mathrm{B}$ & .01 & $1.05(0.0034)$ \\
\hline Gove & mode $\mathrm{MO} \rightarrow \mathrm{M}$ & .12 & $3.28 * *(0.0006)$ \\
\hline Gove & mode $\mathrm{MO} \rightarrow \mathrm{C}$ & -.05 & $1.18(0.0003)$ \\
\hline Gove & e mode $\mathrm{MO} \rightarrow \mathrm{A}$ & -.12 & $2.01 *(0.0038)$ \\
\hline Num & partners $\mathrm{NU} \rightarrow \mathrm{B}$ & .05 & $.61(0.0064)$ \\
\hline Num & partners NU $\rightarrow \mathrm{M}$ & -.11 & $2.15^{*}(0.0014)$ \\
\hline Num & partners $\mathrm{NU} \rightarrow \mathrm{C}$ & .09 & $1.88+(0.0008)$ \\
\hline Num & partners $\mathrm{NU} \rightarrow \mathrm{A}$ & .00 & $.71(0.0010)$ \\
\hline
\end{tabular}


Table 5: R-square results

\begin{tabular}{|l|c|c|}
\hline $\begin{array}{l}\text { Dependent Variable } \\
(\mathrm{N}=289)\end{array}$ & $\begin{array}{c}\mathbf{R}^{\mathbf{2}} \\
\text { (excl. control variables) }\end{array}$ & $\begin{array}{c}\mathbf{R}^{\mathbf{2}} \\
\text { (incl. control variables) }\end{array}$ \\
\hline Bureaucracy (B) & .103 & .109 \\
\hline Market (M) & .134 & .190 \\
\hline Clan (C) & .187 & .226 \\
\hline Adhocracy (A) & .063 & .095 \\
\hline Average & .122 & .155 \\
\hline
\end{tabular}

